\title{
Diversity and phenotypic analyses of salt- and heat-tolerant wild bean Phaseolus filiformis rhizobia native of a sand beach in Baja California and description of Ensifer aridi sp. nov.
}

\author{
Guadalupe Rocha ${ }^{1}$ - Antoine Le Queré ${ }^{2}$ - Arturo Medina ${ }^{1}$ - Alma Cuéllar ${ }^{1}$. José-Luis Contreras ${ }^{3} \cdot$ Ricardo Carreño $^{1}$. \\ Rocío Bustillos ${ }^{1}$. Jesús Muñoz-Rojas ${ }^{1} \cdot$ María del Carmen Villegas $^{4} \cdot$ Clémence Chaintreuil $^{2} \cdot$ Bernard Dreyfus $^{2}$. \\ José-Antonio Munive ${ }^{1}$ (1)
}

Received: 23 January 2019 / Revised: 19 September 2019 / Accepted: 10 October 2019 / Published online: 28 October 2019

(c) The Author(s) 2019

\begin{abstract}
In northern Mexico, aridity, salinity and high temperatures limit areas that can be cultivated. To investigate the nature of nitrogen-fixing symbionts of Phaseolus filiformis, an adapted wild bean species native to this region, their phylogenies were inferred by MLSA. Most rhizobia recovered belong to the proposed new species Ensifer aridi. Phylogenetic analyses of nodC and nifH show that Mexican isolates carry symbiotic genes acquired through horizontal gene transfer that are divergent from those previously characterized among bean symbionts. These strains are salt tolerant, able to grow in alkaline conditions, high temperatures, and capable of utilizing a wide range of carbohydrates and organic acids as carbon sources for growth. This study improves the knowledge on diversity, geographic distribution and evolution of bean-nodulating rhizobia in Mexico and further enlarges the spectrum of microsymbiont with which Phaseolus species can interact with, including cultivated bean varieties, notably under stressed environments. Here, the species Ensifer aridi sp. nov. is proposed as strain type of the Moroccan isolate LMR001 ${ }^{\mathrm{T}}\left(=\mathrm{LMG} 31426^{\mathrm{T}} ;=\right.$ HAMBI $\left.3707^{\mathrm{T}}\right)$ recovered from desert sand dune.
\end{abstract}

Keywords Legume-rhizobium symbiosis $\cdot$ Ensifer $\cdot$ Wild bean $\cdot$ Salt tolerance

Communicated by Erko Stackebrandt.

Electronic supplementary material The online version of this article (https://doi.org/10.1007/s00203-019-01744-7) contains supplementary material, which is available to authorized users.

José-Antonio Munive

joseantonio.munive@correo.buap.mx

1 Centro de Investigaciones en Ciencias Microbiológicas, Instituto de Ciencias, Benemérita Universidad Autónoma de Puebla, Av. San Claudio S/N, CP-72570 Puebla, Mexico

2 IRD/CIRAD/UM2/Supagro-UR 040 Laboratoire des Symbioses Tropicales et Méditerranéennes, 34398 Montpellier, France

3 Facultad de Arquitectura, Benemérita Universidad Autónoma de Puebla, Av. San Claudio S/N, CP-72570 Puebla, Mexico

4 Helyx Affaires SC, Rumania 923-2. Col. Portales-Sur. Alcaldía Benito Juárez, CP-03300 Cd. de México, Mexico

\section{Introduction}

The Leguminosae (Fabaceae) is the third largest family of flowering plants with approximately 730 genera and over 19,400 species (Mabberly 1997; Lewis et al. 2005). Grain legumes such as soybeans, beans, peas, or peanuts are agriculturally and economically important. Their particularly high protein content represents an ecological alternative to cattle farming. Furthermore, their capacity to develop a natural mutualistic interaction with symbiotic nitrogen-fixing bacteria (referred as rhizobia) can reduce nitrogen fertilizer use which requires, however, the presence of compatible, competitive and efficient microbial partners.

Common bean (Phaseolus vulgaris L.) represents the most important source of proteins for low-income populations in Latin America and Africa (Ribeiro et al. 2009). The genus Phaseolus comprises around 50 species, all indigenous to the Americas. Among these, P. lunatus, $P$. vulgaris, $P$. polyanthus, $P$. coccineus and $P$. acutifolius were domesticated by pre-Hispanic civilizations and are now widely cultivated for human consumption. Given the 
potential interest in promoting natural symbioses for plant growth improvement and adaptation to a changing environment, there is interest in investigating the rhizobial partners that can develop the symbiosis with wild bean adapted to stressed environments, compare their diversity and estimate their symbiosis capacities with those of cultivated beans' symbionts. Phaseolus filiformis (also named slimjim bean, slender-stem bean, or Wright's phaseolus), is a wild bean species native to the southwestern United States and northwestern Mexico, a region subjected to frequent droughts and salt stresses (Shreve and Wiggins 1964; Hickman 1993; Roskov et al. 2013).

Most of the described rhizobial species belong to the subclass Alphaproteobacteria (Lindström and Mousavi 2010; Lindström 2015), but there are also a few representatives within the subclass Betaproteobacteria also called beta-rhizobia (Moulin et al. 2001; Chen et al. 2003). Most reported phylogenies of rhizobia nodulating Phaseolus species have placed them in the genera Rhizobium and Bradyrhizobium (Servín-Garcidueñas et al. 2014). Even though most legumes reported in the tribe Phaseoleae are nodulated by Bradyrhizobium strains (Martinez-Romero 2009), P. vulgaris and closed species are mainly nodulated by Rhizobium strains. However, studies have shown that strains belonging to the genus Ensifer (Sinorhizobium) (E. fredii, E. meliloti and E. americanum) (Herrera-Cervera et al. 1999; Mnasri et al. 2007; Zurdo-Piñeiro et al. 2009; Verástegui-Valdés et al. 2014) can also develop an effective symbiosis with this crop and more recently the beta-rhizobium Paraburkholderia nodosa was found as the main symbiotic partner in the Brazilian Cerrado region (Dall'Agnol et al. 2016).

Due to the need for easy, robust and reliable techniques for the identification and classification of bacterial isolates at the species level, phylogenetic analyses using several conserved and single copy protein-encoding genes (housekeeping genes), with a higher level of sequence divergence than rRNA genes are now encouraged. The ad hoc committee for the redefinition of bacterial species concept has recommended the use of several genes to perform such classification (Stackebrandt et al. 2002). More recently, multilocus sequence analysis (MLSA) which uses a concatenated sequence of multiple markers to infer evolutionary relationships among bacterial isolates was shown as a reliable method to classify species in several genera including Ensifer (Martens et al. 2007, 2008) or Bradyrhizobium (Vinuesa et al. 2008).

The aim of the present work was to isolate and characterize rhizobia nodulating the wild bean species $P$. filiformis and test their capacities to develop the symbiosis with cultivated beans. Isolated strains were genotyped by restriction patterns produced by ARDRA and REP-PCR. To clarify their taxonomic position within the phylogeny of rhizobia, several taxonomic markers (16S rDNA, atpD, dnaK, rpoB, glnA, gyrB, recA, thrC, and $g \ln I I)$ were partially sequenced and analyzed. In addition, two symbiotic genes (nifH and nodC), that reflect the symbiotic properties of rhizobia (Haukka et al. 1998; Laguerre et al. 2001), were studied. This collection was also phenotypically characterized for their capacity to nodulate various hosts including several cultivated bean varieties, carbon source utilization, and tolerance to alkalinity, salinity, and high-temperature conditions.

\section{Materials and methods}

\section{Origin of the strains and culture conditions}

Phaseolus filiformis plants were sampled in the desertic region of Baja California, Mexico $\left(22^{\circ} 55^{\prime} 51.5^{\prime \prime} \mathrm{N}\right.$, $\left.109^{\circ} 48^{\prime} 55.3^{\prime \prime} \mathrm{W}\right)$, at $9.5 \mathrm{~m}$ above sea level on the Santa Maria Bay, Guadalupe Beach. The plants were grown on sandy soil presenting an electrical conductivity of $6.276 \mathrm{ds} \mathrm{m}^{-1}$ (saline soil), an alkaline $\mathrm{pH}\left(\mathrm{H}_{2} \mathrm{O}\right)$ of 7.82 and presented a low cation exchange capacity of $3.16 \mathrm{meq}^{+} / 100 \mathrm{~g}$. The soil was poor, containing $0.07 \%$ of nitrogen, while organic matter was not detectable. All the plants sampled were nodulated. Rhizobial strains were isolated from nodules using the standard procedures described by Vincent (1970), on yeast mannitol agar (YMA) medium (Bergersen 1961). Strains were grown on YMA at $28{ }^{\circ} \mathrm{C}$ and kept in $20 \%$ (v/v) glycerol at $-80^{\circ} \mathrm{C}$. For comparison, we used E. saheli LMG8310 (ORS611), kindly provided by Esperanza Martínez-Romero (Center for Genome Sciences, UNAM, México).

\section{Nodulation tests}

All strains were evaluated for their ability to induce nodules on different host legume species. Plants tested included their natural host (P. filiformis), five different Phaseolus vulgaris varieties (Negro jamapa, peruano, pinto, vaquita and alubia) and five different legume genera (Mimosa pudica, Erythrina americana, Medicago sativa, Cicer arietinum and Lupinus gredensis). Phaseolus seeds were surface sterilized as described previously (Beynon et al. 1980). Erythrina seeds were rinsed in water, scarified mechanically using sandpapers and sterilized by immersion in concentrated sulfuric acid for $10 \mathrm{~min}$, rinsed with sterile water, and left in water overnight. Mimosa seeds were rinsed in water, sterilized by immersion in concentrated sulfuric acid for $10 \mathrm{~min}$, rinsed with sterile water, and left in water overnight. Medicago and Lupinus seeds were submerged in $70 \%$ alcohol for $10 \mathrm{~min}$, immersed in $25 \%$ sodium hypochlorite solution for $15 \mathrm{~min}$ and rinsed with sterile water. Cicer seeds followed the latter protocol, but they were soaked in a boiling water bath for 
$50 \mathrm{~s}$ prior to treatment exposure (modified from Somasegaran and Hoben 1994).

Seeds were placed onto water agar $(0.75 \% \mathrm{w} / \mathrm{v})$ in Petri dishes until germination. Germinated seedlings were transferred to agar slants ( $20 \mathrm{ml}$ of agar in $50 \mathrm{ml}$ tube) of Jensen's N-free medium (Somasegaran and Hoben 1994). Plants were incubated at $20{ }^{\circ} \mathrm{C}$ with a 16 -h light, 8 -h dark cycle (Knight et al. 1986). A single colony of each isolate was picked from YMA plates and grown aerobically in yeast extract mannitol broth (YM) on an orbital shaker (180 rpm) at $28{ }^{\circ} \mathrm{C}$. Each seedling was inoculated with $1 \mathrm{ml}$ bacterial culture at exponential growth phase (Somasegaran and Hoben 1994). For each plant species tested, controls consisted of non-inoculated seedlings, either supplied with mineral nitrogen (as $0.1 \% \mathrm{KNO}_{3}$ in nutrient solution) or grown without nitrogen. Roots of plants were observed for root nodule formation 3-4 weeks after inoculation.

\section{PCR amplification and sequencing of housekeeping genes for MLSA, ribosomal and symbiotic genes}

Total DNA was extracted using the Wizard Genomic DNA Purification Kit (Promega Corporation, USA), according to the manufacturer's protocol. PCR was performed in a 2400 GeneAmp PCR Systems ${ }^{\circledR}$ Perkin Elmer thermocycler.
Internal fragments of the housekeeping genes, atpD (ATP synthase F1, beta subunit) and glnII (glutamine synthetase II) (Vinuesa et al. 2005); rрoB (RNA polymerase, beta subunit) and gyrB (DNA gyrase B subunit) (Martens et al. 2008); recA (recombinase A) (Gaunt et al. 2001), dnaK (heat shock protein HSP70) (Stepkowski et al. 2003); glnA (glutamine synthetase type I) and $\operatorname{thr} C$ (threonine synthase) (Martens et al. 2007), as well as the 16S rDNA gene, and the symbiosis-related genes nodC ( $\mathrm{N}$-acetylglucosaminyltransferase) and nifH (dinitrogenase reductase) (Laguerre et al. 2001), were amplified using the conditions described in Table 1.

PCR products and their concentration were verified by electrophoresis on a $1 \%$ agarose gel stained with ethidium bromide. A molecular size marker (GeneRuler $1 \mathrm{~Kb}$ DNA Ladder) was included to estimate the length of the amplification products. The amplified products were purified to remove salts, polymerase and excess primers and nucleotides, using a Qiaquick PCR purification kit (Qiagen) according to the manufacturer's instructions. Concentration of purified products was measured in a spectrophotometer NanoDrop ${ }^{\circledR}$ ND-1000 (NanoDrop Technologies, Wilmington, DE). Sequencing was performed by the Genoscreen company service (Applied Biosystems 3730XL DNA sequencer). Consensus sequences were obtained using the AutoAssembler software (Applied Biosystems).

Table 1 Primers and PCR cycling conditions used in this work

\begin{tabular}{|c|c|c|c|}
\hline Primer & Sequence $\left(5^{\prime}-3^{\prime}\right)$ & PCR cycling conditions & References \\
\hline REPIR-1 REP2-1 & $\begin{array}{l}\text { IIIICGICGICATCIGGC } \\
\text { ICGICTTTATCIGGCTAC }\end{array}$ & $\begin{array}{l}7^{\prime} 95^{\circ} \mathrm{C}, \times 35\left(1^{\prime} 94^{\circ} \mathrm{C}, 1^{\prime} 40^{\circ} \mathrm{C}, 8^{\prime} 65^{\circ} \mathrm{C}\right), 16^{\prime} \\
65^{\circ} \mathrm{C}, \infty 20^{\circ} \mathrm{C}\end{array}$ & Versalovic et al. (1994) \\
\hline $\begin{array}{l}\text { UN27F } \\
\text { UN1392R }\end{array}$ & $\begin{array}{l}\text { TAGAGTTTGATCCTGGCTCAG } \\
\text { CAGGGGCGGTGTGTACA }\end{array}$ & $\begin{array}{l}3^{\prime} 95^{\circ} \mathrm{C}, \times 26\left(30^{\prime \prime} 94^{\circ} \mathrm{C}, 1^{\prime} 57^{\circ} \mathrm{C}, 1^{\prime} 10^{\prime \prime} 72^{\circ} \mathrm{C}\right) \\
10^{\prime} 72^{\circ} \mathrm{C}, \infty 20^{\circ} \mathrm{C}\end{array}$ & Biodiversa Inc., México \\
\hline $\begin{array}{l}\text { atpD255F } \\
\text { atpD782R }\end{array}$ & $\begin{array}{l}\text { GCTSGGCCGCATCMTSAACGTC } \\
\text { GCCGACACTTCMGAACCNGCCTG }\end{array}$ & $\begin{array}{l}3^{\prime} 30^{\prime \prime} 95^{\circ} \mathrm{C}, \times 30\left(1^{\prime} 93.5^{\circ} \mathrm{C}, 40^{\prime \prime} 55^{\circ} \mathrm{C}, 1^{\prime}\right. \\
\left.72^{\circ} \mathrm{C}\right), 5^{\prime} 72^{\circ} \mathrm{C}, \infty 15^{\circ} \mathrm{C}\end{array}$ & Vinuesa et al. (2005) \\
\hline glnII-12F glnII-689R & $\begin{array}{l}\text { YAAGCTCGAGTACATYTGGCT TGC } \\
\text { ATGCCSGAGCCGTTCCA }\end{array}$ & $\begin{array}{l}3^{\prime} 30^{\prime \prime} 95^{\circ} \mathrm{C}, \times 30\left(1^{\prime} 93.5^{\circ} \mathrm{C}, 1^{\prime} 58^{\circ} \mathrm{C}, 1^{\prime} 72^{\circ} \mathrm{C}\right) \\
5^{\prime} 72^{\circ} \mathrm{C}, \infty 15^{\circ} \mathrm{C}\end{array}$ & Vinuesa et al, 2005 \\
\hline $\begin{array}{l}\text { TSdnaK2 } \\
\text { TSdnaK4 }\end{array}$ & $\begin{array}{l}\text { GTACATGGCCTCGCCGAGCTTCA } \\
\text { GGCAAGGAGCCGCAYAAGG }\end{array}$ & $\begin{array}{l}5^{\prime} 94^{\circ} \mathrm{C}, \times 35\left(30^{\prime \prime} 94^{\circ} \mathrm{C}, 1^{\prime} 60^{\circ} \mathrm{C}, 45^{\prime \prime} 72^{\circ} \mathrm{C}\right), 7^{\prime} \\
72^{\circ} \mathrm{C}, \infty 20^{\circ} \mathrm{C}\end{array}$ & Stepkowsky et al. (2003) \\
\hline $\begin{array}{l}\operatorname{gln} A 144 \mathrm{~F} \\
\operatorname{gln} \mathrm{A} 1142 \mathrm{R}\end{array}$ & $\begin{array}{l}\text { GTCATGTTCGACGGYTCYTCG } \\
\text { TGGAKCTTGTTCTTGATGCCG }\end{array}$ & $\begin{array}{l}3^{\prime} 30^{\prime \prime} 95^{\circ} \mathrm{C}, \times 30\left(1^{\prime} 93.5^{\circ} \mathrm{C}, 1^{\prime} 61^{\circ} \mathrm{C}, 1^{\prime} 72^{\circ} \mathrm{C}\right) \\
5^{\prime} 72^{\circ} \mathrm{C}, \infty 20^{\circ} \mathrm{C}\end{array}$ & Martens et al. (2007) \\
\hline $\begin{array}{l}\text { gyrB343F } \\
\text { gyrB1043R }\end{array}$ & $\begin{array}{l}\text { TTCGACCAGAAYTCCTAYAAGG } \\
\text { AGCTTGTCCTTSGTCTGCG }\end{array}$ & $\begin{array}{l}5^{\prime} 96^{\circ} \mathrm{C}, \times 35\left(30^{\prime \prime} 94^{\circ} \mathrm{C}, 30^{\prime \prime} 59^{\circ} \mathrm{C}, 1^{\prime} 72^{\circ} \mathrm{C}\right), 3^{\prime} \\
72^{\circ} \mathrm{C}, \infty 20^{\circ} \mathrm{C}\end{array}$ & Martens et al. (2008) \\
\hline $\begin{array}{l}\operatorname{recA} 12^{\mathrm{a}} \\
\operatorname{recA} 555\end{array}$ & $\begin{array}{l}\text { GTAGAGGAYAAATCGGTGGA } \\
\text { CGRATCTGGTTGATGAAGATCACCAT }\end{array}$ & $\begin{array}{l}5^{\prime} 94^{\circ} \mathrm{C}, \times 35\left(30^{\prime \prime} 94^{\circ} \mathrm{C}, 1^{\prime} 50^{\circ} \mathrm{C}, 45^{\prime \prime} 72^{\circ} \mathrm{C}\right), 7^{\prime} \\
72^{\circ} \mathrm{C}, \infty 20^{\circ} \mathrm{C}\end{array}$ & Gaunt et al. (2001) \\
\hline $\begin{array}{l}\text { rpoB83F } \\
\text { rpoB1061R }\end{array}$ & $\begin{array}{l}\text { CCTSATCGAGGTTCACAGAAGGC } \\
\text { AGCGTGTTGCGGATATAGGCG }\end{array}$ & $\begin{array}{l}5^{\prime} 96^{\circ} \mathrm{C}, \times 35\left(30^{\prime \prime} 94^{\circ} \mathrm{C}, 30^{\prime \prime} 59^{\circ} \mathrm{C}, 1^{\prime} 72^{\circ} \mathrm{C}\right), 3^{\prime} \\
72^{\circ} \mathrm{C}, \infty 20^{\circ} \mathrm{C}\end{array}$ & Martens et al. (2008) \\
\hline $\begin{array}{l}\text { thrC577F } \\
\text { thrC1231R }\end{array}$ & $\begin{array}{l}\text { GGCAMKTTCGACGAYTGCCAG } \\
\text { GGRAATTTDGCCGGRTGSGC }\end{array}$ & $\begin{array}{l}3^{\prime} 30^{\prime \prime} 95^{\circ} \mathrm{C}, \times 30\left(1^{\prime} 93.5^{\circ} \mathrm{C}, 1^{\prime} 55^{\circ} \mathrm{C}, 1^{\prime} 72^{\circ} \mathrm{C}\right), \\
5^{\prime} 72^{\circ} \mathrm{C}, \infty 20^{\circ} \mathrm{C}\end{array}$ & Martens et al. (2007) \\
\hline $\begin{array}{l}\operatorname{nodCF} \\
\operatorname{nodCI}\end{array}$ & $\begin{array}{l}\text { AYGTHGTYGAYGACGGTTC } \\
\text { CYGGACAGCCANTCKCTATTG }\end{array}$ & $\begin{array}{l}5^{\prime} 95^{\circ} \mathrm{C}, \times 35\left(30^{\prime \prime} 94^{\circ} \mathrm{C}, 30^{\prime \prime} 56^{\circ} \mathrm{C}, 1^{\prime} 72^{\circ} \mathrm{C}\right), 7^{\prime} \\
72^{\circ} \mathrm{C}, \infty 20^{\circ} \mathrm{C}\end{array}$ & Laguerre et al. (2001) \\
\hline $\begin{array}{l}\text { nifHF } \\
\text { nifHI }\end{array}$ & $\begin{array}{l}\text { TACGGNAARGGSGGNATCGGCAA } \\
\text { AGCATGTCYYCSAGYTCNTCCA }\end{array}$ & $\begin{array}{l}5^{\prime} 95^{\circ} \mathrm{C}, \times 35\left(30^{\prime \prime} 94^{\circ} \mathrm{C}, 30^{\prime \prime} 60^{\circ} \mathrm{C}, 45^{\prime \prime} 72^{\circ} \mathrm{C}\right) \\
7^{\prime} 72^{\circ} \mathrm{C}, \infty 20^{\circ} \mathrm{C}\end{array}$ & Laguerre et al. (2001) \\
\hline
\end{tabular}

${ }^{a}$ Modified from Gaunt et al. (2001) 


\section{Sequence alignment and phylogenetic analyses}

Sequences were compared with those of the selected strains including type material available from Genbank database at the time of writing. The GenBank accession numbers are included in supplementary materials (Supp. Table S1 and Supp. Table S2). Concatenated sequences were generated using DNAsp v5 (Librado and Rozas 2009). Nucleotide sequence alignments were made using CLUSTAL_X (Thompson et al. 1997), and corrected manually using GeneDoc (Nicholas et al. 1997). Maximum-likelihood (ML) analyses were performed with MEGA version 7.0 (Kumar et al. 2016; Tamura et al. 2011). ML analyses were performed using the models with the lowest Bayesian information criterion score. All analyses were performed with at least 500 bootstrap replications.

\section{ARDRA and REP-PCR genomic fingerprinting}

PCR-based locus-specific RFLP ribotyping can be successfully applied for the differentiation of bacterial strains that display a low degree of heterogeneity within the rRNA operons (Olive and Bean 1991). Amplified 16S rDNA was digested with the restriction enzymes AluI, CfoI, HinfI and NheI purchased at Roche Diagnostics GmbH (Germany). The digested DNA was separated in $2.5 \%$ (w/v) agarose gel, for $3 \mathrm{~h}$ at a constant voltage of $70 \mathrm{~V} \mathrm{~cm}^{-1}$ at $4{ }^{\circ} \mathrm{C}$, and further stained with ethidium bromide. REP-PCR generates DNA fingerprints that allow the discrimination of bacterial strains (Versalovic et al. 1994). The REP-PCR amplifications were performed using the conditions described in Table 1. The REP-PCR profiles were visualized under ultraviolet light after staining with ethidium bromide. The resulting fingerprints were analyzed by the BioNumerics V4.0 software package (Applied Maths, Ghent, Belgium). The similarity among digitized profiles was calculated using the Pearson correlation, and an average linkage (UPGMA) dendrogram was derived from the profiles.

\section{Effect of temperature, salt concentration and pH on bacterial growth}

To estimate the tolerance of isolated rhizobia to salt, Ensifer strains were first pre-cultivated at $28{ }^{\circ} \mathrm{C}$ for $24 \mathrm{~h}$ in $5 \mathrm{ml}$ of YM broth (pH 6.8) with shaking (180 rpm). This volume was then used to inoculate $50 \mathrm{ml}$ of YM media to reach a target initial titer of $8 \times 10^{8} \mathrm{CFU} / \mathrm{ml}$. Bacterial tolerance was estimated by inoculating modified YMA medium containing either $0.85 \mathrm{mM}, 10 \mathrm{mM}, 50 \mathrm{mM}, 100 \mathrm{mM}, 150 \mathrm{mM}$, $200 \mathrm{mM}, 300 \mathrm{mM}, 400 \mathrm{mM}, 500 \mathrm{mM}, 600 \mathrm{mM}, 800 \mathrm{mM}$ or $1000 \mathrm{mM} \mathrm{NaCl}$. Plates were incubated at $28^{\circ} \mathrm{C}$ for 7 days, and colony-forming units per milliliter $(\mathrm{CFU} / \mathrm{ml})$ were calculated for each sample by massive stamping drop plate technique (Corral-Lugo et al. 2012). For the analysis of temperature and $\mathrm{pH}$ effects on bacterial growth, the strains were pre-cultivated as previously described but incubated at different temperatures from $28^{\circ} \mathrm{C}, 32^{\circ} \mathrm{C}, 37^{\circ} \mathrm{C}$ up to $40^{\circ} \mathrm{C}$, or at different pHs $(5.3,6.8,8.3$ and 9.5). Bacterial growth was estimated as previously described (Corral-Lugo et al. 2012).

\section{Determination of carbon assimilation profiles}

Oxidation of 48 carbon sources was tested with the API 50 $\mathrm{CH}$ systems (API strips, Biomérieux, France) using overnight YM broth cultures grown at $28{ }^{\circ} \mathrm{C}$ according to the manufacturer's protocol. The results were recorded after $24 \mathrm{~h}$ and $48 \mathrm{~h}$ of incubation at $28^{\circ} \mathrm{C}$. Each strain was tested in API 50CH on two separate occasions and showed good reproducibility.

\section{Genome-based species delineation}

The average nucleotide identity (ANI) (Goris et al. 2007) and digital DNA-DNA hybridization ( $\mathrm{dDDH})$ estimates (Meier-Kolthoff et al. 2013) were used to determine the molecular delineation of Ensifer aridi strains from neighboring species. The accession numbers of all genome sequences used here are reported in Supplementary table S3. These included the genome sequences of strains LEM451 and LEM457 representing the majority of strains recovered from $P$. filiformis as well as LMR001 ${ }^{\mathrm{T}}$ and LMR013 recovered from the Merzouga desert in Morocco and TP6 and TW10 isolated from the Indian Thar desert. These genomic sequences were compared to available genome sequences from all Ensifer type strains available at the time of writing including that of E. saheli LMG $7837^{\mathrm{T}}$, the closest relative of Ensifer aridi (Supplementary table S3). For the ANI calculation, alignment options used were $70 \%$ minimal identity over more than $700 \mathrm{bp}$ in fragment windows of $1000 \mathrm{bp}$ with a 200 bp step size on reciprocal best hits (two-way ANI). For the dDDH estimation, we used the Genome to Genome Distance Calculator 2.1 (GGDC) with the BLAST + alignment method which uses the generalized linear model with the recommended settings (Meier-Kolthoff et al. 2013). The TYGS method using recommended settings was used to show species delineation and for phylogenomic tree construction (Meier-Kolthoff and Göker 2019).

\section{Results}

\section{Isolation of rhizobia and nodulation tests}

Phaseolus filiformis was the primary natural legume plant present on the sampled site. Ten rhizobial strains were isolated from nodules of $P$. filiformis directly growing in the 
sand and tested for nodulation on eleven different host legumes. Our tests did not reveal any variation of their respective nodulation phenotype. All these strains were capable of nodulating their original host, $P$. filiformis, as well as all the bean varieties tested. However, using the culture conditions used here, they were not capable of nodulating the other legumes tested (M. pudica, E. americana, M. sativa, C. arietinum nor L. gredensis).

\section{Genomic fingerprinting}

The PCR-RFLP of the 16S rDNA genes and a REP-PCR genomic fingerprinting of rhizobia recovered were carried out. Strains were categorized in ten genotypes by combination of the restriction patterns from the four enzymes and from REP-PCR fingerprinting patterns (data not shown). Given the high diversity obtained, all isolated strains were further analyzed.

\section{Phylogenetic analyses of $P$. filiformis symbiotic isolates}

The maximum-likelihood tree based on nearly full $16 \mathrm{~S}$ rDNA gene sequences (Fig. 1) showed that the P. filiformis isolates belonged to the Ensifer genus and grouped into three different clusters. The majority of the partial $16 \mathrm{~S}$ rDNA sequences (8/10) showed high sequence similarities to those of Ensifer strains recovered from Asian or African deserts recently described, and for which the name "Ensifer aridi" was proposed based on genomic data which included the two P. filiformis rhizobial strains LEM451 and LEM457 (Le Queré et al. 2017). The 16S rDNA sequences of the strains LEM451, LEM453, LEM457 and LEM462 were $100 \%$ identical over $1227 \mathrm{bp}$ aligned sequences to that of African and Asian "Ensifer aridi" isolates; LEM459 and LEM466 presented a single substitution, while LEM551 and LEM465 presented 2 and 4 substitutions, respectively. The partial 16S rDNA sequence of one isolate (LEM468) was identical to that of Ensifer saheli LMG $7837^{\mathrm{T}}$ that is closely related to the "Ensifer aridi" clade with which it shares 1220 bases out of the 1227 sequenced. Finally, LEM456 was closely related to E. meliloti; differing only 2 nucleotides along the 1227 aligned sequences ( $99.8 \%$ identity).

To better resolve the position of the strains among Ensifer species, we then constructed a phylogenetic tree upon concatenation of three housekeeping genes ( $a t p D$, recA and $g \ln I$ ) that are available for most of Ensifer species (Fig. 2). The tree obtained presented several differences with that obtained based on the 16S rDNA phylogeny. In particular, the phylogenetic proximity between strain LEM468 and $E$. saheli, and that obtained between the rest of Mexican strains (except LEM456) and E. kostiense were not confirmed. The strain LEM468, that showed partial 16S rDNA sequence

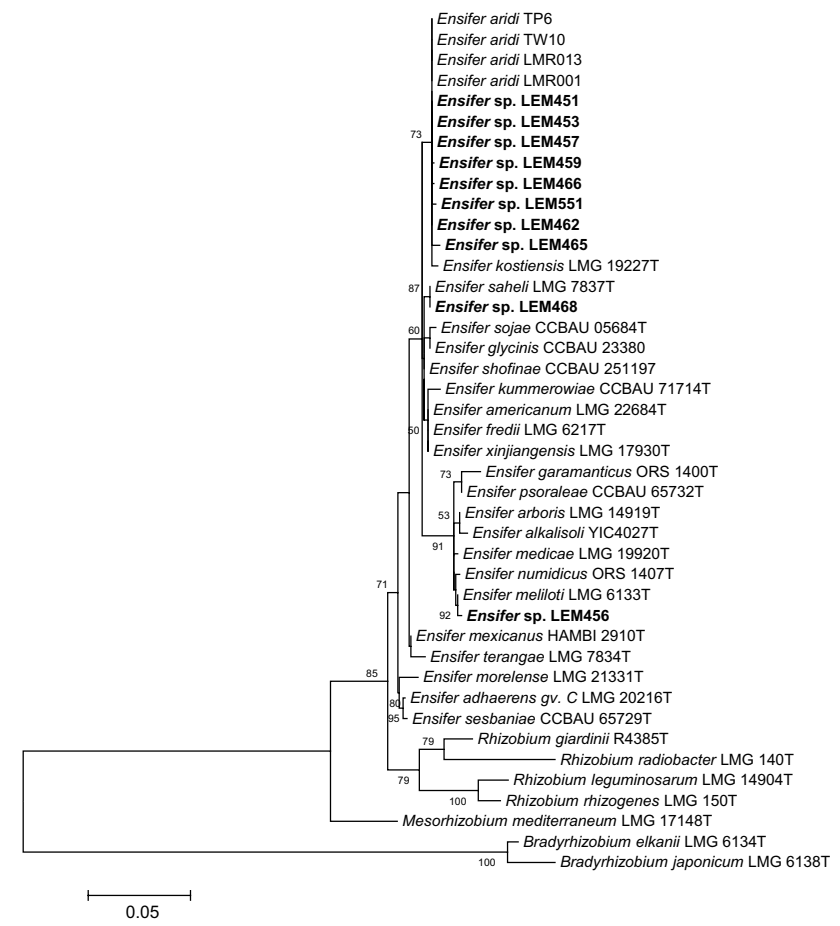

Fig. 1 Maximum-likelihood tree based on partial 16S rDNA gene sequences showing the evolutionary relationships between Ensifer strains isolated from Phaseolus filiformis nodules in Mexico (bold) and reference strains. The analysis was based on 1229 nucleotides alignment. The significance of each branch is indicated by the bootstrap value calculated for 500 replicates (only values higher than $50 \%$ are indicated). Scale bar indicates 5\% substitution per site. Accession numbers of sequences used are reported in supplementary Table S1

identical to Ensifer saheli LMG $7837^{\mathrm{T}}$, clustered together with the strains of the "Ensifer aridi" clade. Furthermore, in contrast to the $16 \mathrm{~S}$ rDNA sequence-based phylogeny, this large group of Ensifer strains presented a higher sequence similarity with $E$. saheli than with $E$. kostiense, even though the latter species clustered together within a clade that encompassed $E$. aridi and $E$. saheli strains which was supported by a bootstrap of $68 \%$. Finally, the strain LEM 456 was separated from the remaining Mexican isolates and was related to the species E. kummerowiae and E. meliloti, which is in good agreement with the $16 \mathrm{~S}$ rDNA phylogeny.

Individual analyses of the eight housekeeping genes partially sequenced showed that the $r e c A$ gene presented the highest similarity with $100 \%$ identity between sequences of the nine Mexican strains clustering with "Ensifer aridi". The partial rpoB and $a t p D$ gene sequences were identical among these nine strains except for LEM466 which presented one and four substitutions, respectively. The $\mathrm{gyr} B$ sequences presented from 99.6 to $100 \%$ sequence similarities and the thrC alignment presented from 99 to $100 \%$ sequence similarities among this group of nine $P$. filiformis isolates. The partial gene sequences of $g \ln I I$ were identical 


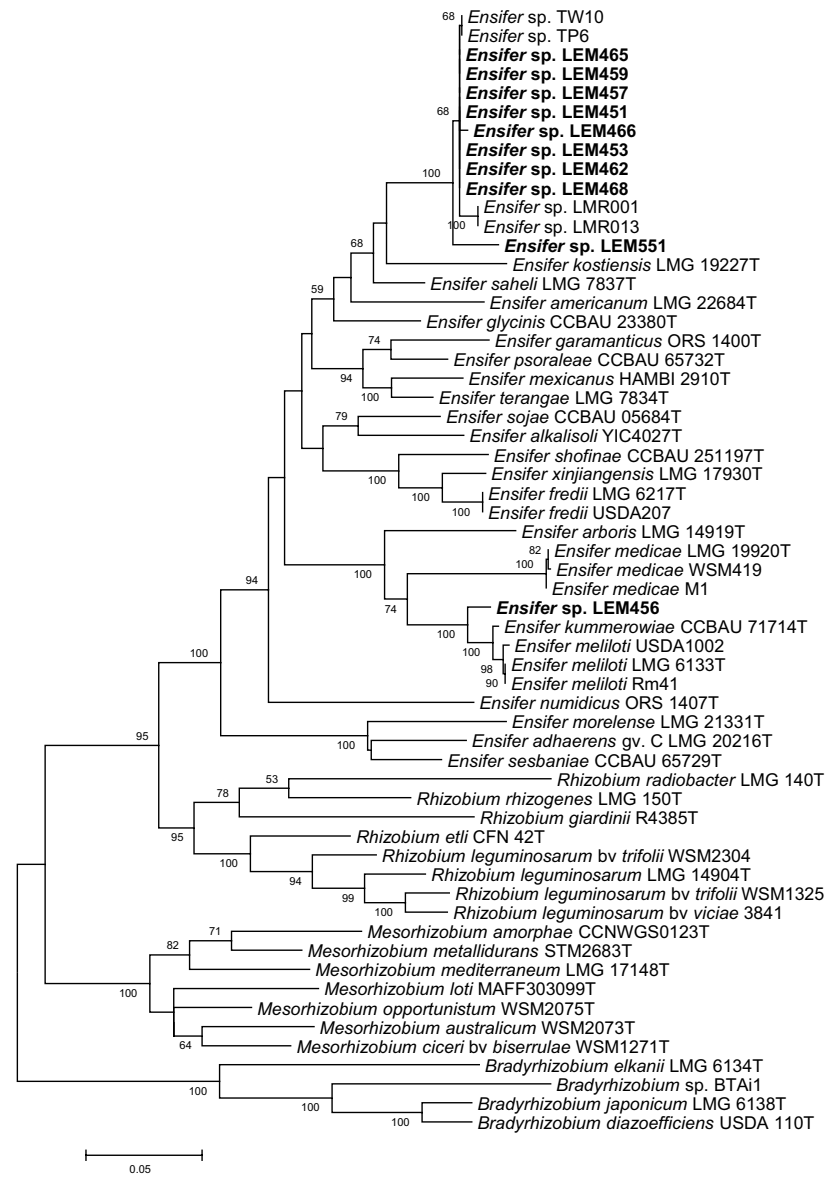

Fig. 2 Maximum-likelihood tree based on concatenated atpD-recAglnII partial gene sequences showing the evolutionary relationships between Ensifer strains isolated from Phaseolus filiformis nodules in Mexico (bold) and reference strains. The analysis was based on 1245 nucleotides alignment. The significance of each branch is indicated by the bootstrap value calculated for 500 replicates (only values higher than 50\% are indicated). Scale bar indicates 5\% substitution per site. Accession numbers of sequences used are reported in supplementary Table S1

for this group of strains except for LEM551 which showed 94.9\% sequence similarity. In contrast to these six housekeeping genes, the alignment of dnaK partial sequences presented more divergent sequences for strains LEM466 and LEM551 which presented, respectively, 91.9 and $86.3 \%$ sequence similarities with the remaining sequences from the strains that clustered within the $E$. aridi clade. The $\operatorname{gln} A$ partial sequence alignment showed 90.6-100\% sequence similarities between these nine strains. The sequence similarities between LEM456 and E. meliloti strains were also high. Indeed, when comparing these eight housekeeping gene sequences between LEM456 and six Ensifer meliloti strains, the recA gene presented similarity ranging from 97.3 to $100 \%$. For the remaining markers, dnaK, rpoB, atpD, gyrB, thrC, glnA and $g \ln I I$, similarities ranged, respectively, from 97.5 to $99.5 \%, 97.4$ to $99.1 \%$,
96.8 to $98.4 \%, 96.9$ to $99.8 \%, 97.6$ to $99.8 \%, 96.8$ to $99.7 \%$ and 97.7 to $100 \%$.

Analysis of the alignment obtained from concatenated sequences of the six housekeeping genes $r e c A, a t p D$, gyr $B$, $r p o B, g \ln I I$ and $t h r C$ from the ten Mexican isolates with strains from the closest Ensifer species identified were performed (Fig. 3). This confirmed that nine of the strains are closely related to the species "Ensifer aridi" forming a branch with strong bootstrap support (100\%) with which they shared $98.9-99.9 \%$ identity over the 3213 bp concatenated sequences (Fig. 3). Using this alignment, the strain LEM456 clustered clearly (bootstrap of $100 \%$ ) within the clade that included the six E. meliloti strains and with which it shared from 97.5 to $99.3 \%$ sequence similarities.

\section{Analysis of symbiotic nodC and nifH genes}

Symbiotic genes reflect the bacterial symbiotic properties of rhizobia (Haukka et al. 1998; Laguerre et al. 2001). To explore the symbiotic diversity of $P$. filiformis isolates, two symbiotic genes (nodC and nifH) were partially sequenced for eight isolates and their phylogenies compared to those obtained using housekeeping genes. Based on differences along a 722 pb DNA fragment of nodC, all rhizobial isolates compared grouped together in a single clade related to nodC sequences from Ensifer strains isolated from Acacia macracantha (Vachellia macracantha) nodules in Peru (Fig. 4, Supp. Table S2). The genetic diversity of a $652 \mathrm{pb}$ DNA fragment corresponding to the partial sequences of the nitrogen fixation gene nifH among the Mexican Ensifer strains reported here showed a greater sequence divergence. However, they grouped within a large clade of Ensifer strains belonging to E. americanum, E. meliloti, E. fredii or yet undefined Ensifer species recovered from Phaseolus vulgaris in Europe, Africa, Asia or America, as well as those isolated from Acacia macracantha nodules in Peru or from Leucaena leucocephala in arid-hot river valley area in Panxi, Sichuan, China (Fig. 5, Supp. Table S2).

\section{Effect of salt stress on bacterial growth}

Capable of growing directly on the beach, at sea level, we supposed that the wild bean species $P$. filiformis and its symbiotic partners were able to tolerate high salt concentrations. Here, the tolerance to saline stress for the isolated strains was evaluated using E. saheli LMG 8310 (the closest related species) as control. We confirmed that all Ensifer strains tested were salt tolerant (Table 2). All Ensifer strains tested presented good growth up to $300 \mathrm{mM} \mathrm{NaCl}$. Six strains LEM451, LEM456, LEM457, LEM459, LEM465, LEM466 and E. saheli LMG 8310 can grow at $400 \mathrm{mM} \mathrm{NaCl}$, but strains LEM456, LEM457, LEM459 and LEM465 showed weak growth at this concentration. Strains LEM457 and 


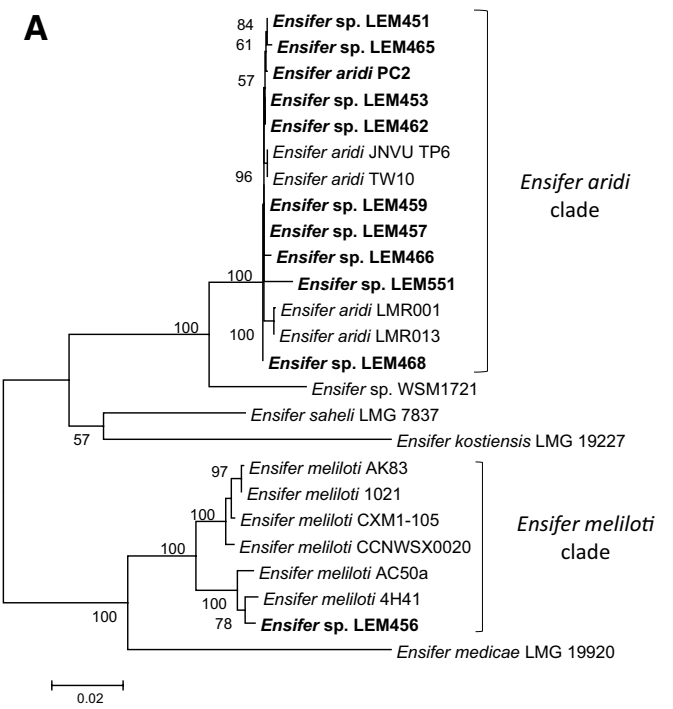

B

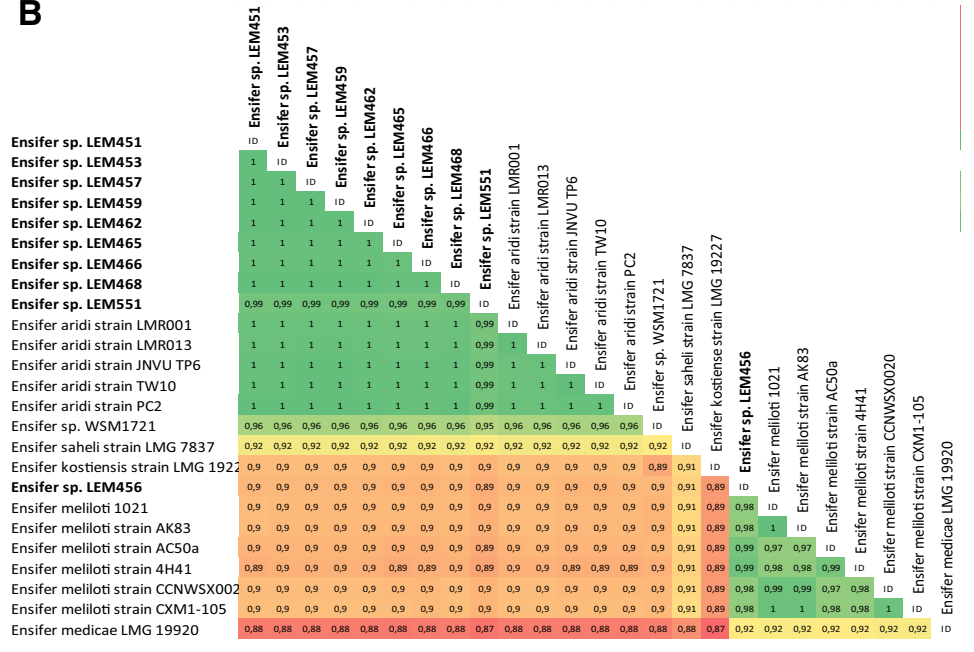

Fig. 3 Analysis of concatenated atpD-glnII-recA-gyrB-rpoB-thrC partial gene sequences between Ensifer strains isolated from Phaseolus filiformis nodules in Mexico (bold) and closely related strains and species. a Maximum-likelihood tree showing the evolutionary relationships. The analysis was based on 3213 nucleotides alignment. The significance of each branch is indicated by the bootstrap value calculated for 500 replicates (only values higher than $50 \%$ are indicated).
Scale bar indicates $2 \%$ substitution per site. b Matrix showing pairwise percentage of similarities between compared strains and species. The percentage of similarities between sequences from two strains is highlighted in red (most divergent) to dark green (most conserved). Accession numbers of sequences used are reported in supplementary Table S1

LEM451, LEM453 and LEM468, meanwhile Ensifer strains LEM457, LEM459, LEM465 and LEM466 did not stand such acid $\mathrm{pH}$.

\section{Determination of carbon utilization profiles}

Ten strains isolated in the present report were characterized for their capacities to utilize a wide range of carbohydrates on API CH50 strips and compared to those of various strains of Ensifer saheli, E. meliloti, E. fredii and E. terangae including type strains (De Lajudie et al. 1994) or to Biolog $\mathrm{GN} 2$ phenotypic microplates obtained from $E$. aridi strains isolated from Indian Thar desert or the Moroccan Merzouga desert (Le Queré et al. 2017) (Supp. Table S4). Variability in carbon source utilization among Ensifer isolates and species was observed. These strains utilize most carbon sources tested (48 different carbon sources), but the patterns of carbon sources utilization were very diverse among the strains isolated from $P$. filiformis. All strains studied here were capable of utilizing D-mannitol, L-arabinose, ribose, methyl- $\beta$ D-xylanopyranoside, D-maltose, D-lyxose and potassium-5-ketogluconate; while they were not capable of metabolizing glycogen. Even strain LEM456, the most divergent strain by MLSA, showed a similar carbon utilization profile. In contrast, most carbon sources tested were not utilized by strain LEM551 which was only capable of using these eight common carbon sources, as well as inositol and salicin that were also metabolized by most Mexican strains. 
Fig. 4 Maximum-likelihood tree based on nodC partial gene sequences showing the evolutionary relationships between Ensifer strains isolated from Phaseolus filiformis nodules in Mexico (bold) and selected strains. The analysis was based on 722 nucleotides alignment. The significance of each branch is indicated by the bootstrap value calculated for 500 replicates (only values higher than $50 \%$ are indicated). Scale bar indicates 5\% substitution per site. Accession numbers of sequences used are reported in supplementary Table S2

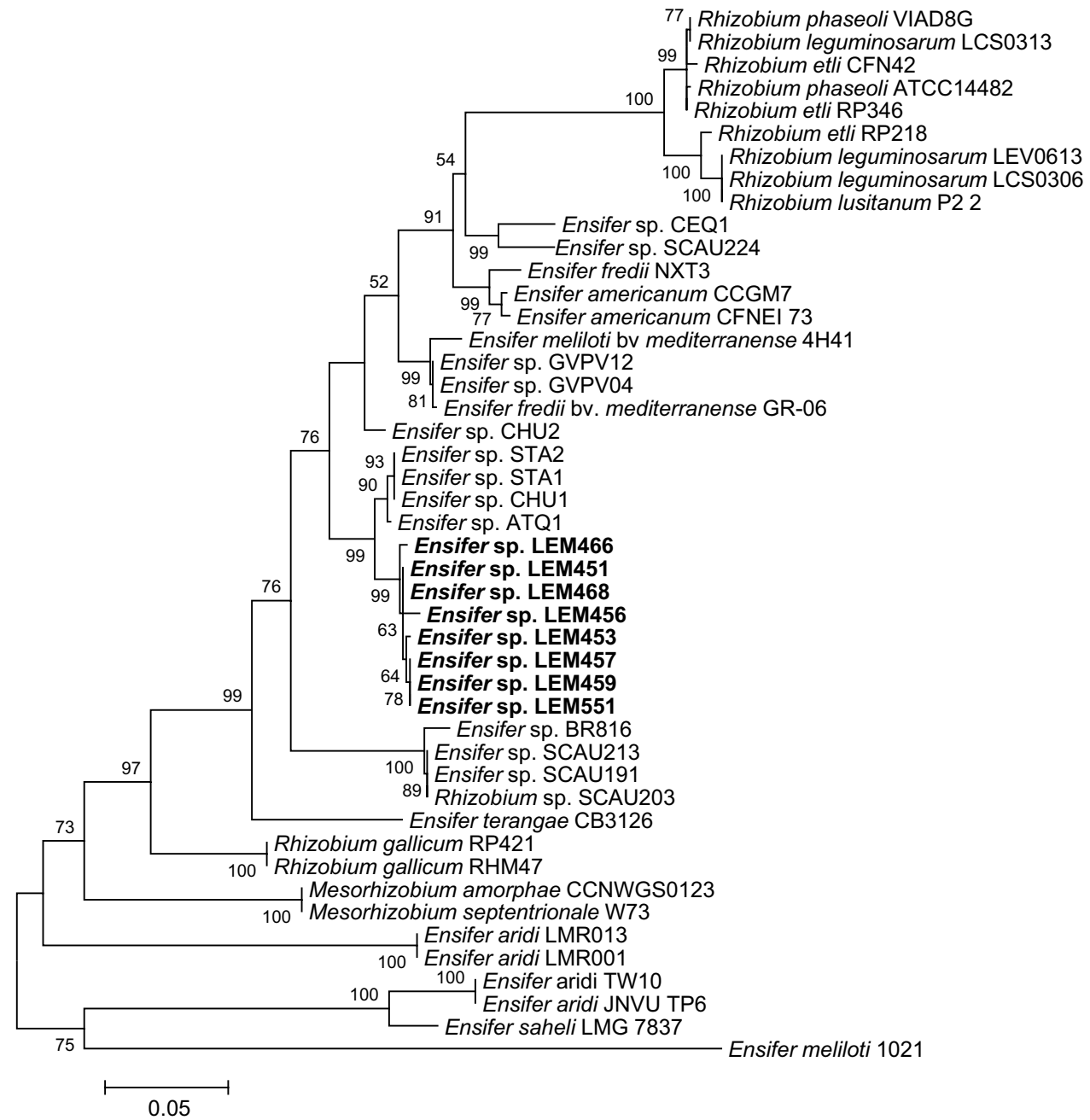

These results indicate metabolic versatility of the wild bean rhizobia presented here. Finally, all the eight Mexican Ensifer aridi strains (LEM451, LEM453, LEM457, LEM459, LEM462, LEM465, LEM466 and LEM468) as well as the two Moroccan strains (LMR001, LMR013) and the two Indian strains (TP6 and TW10) were capable of utilizing glycerol, L-arabinose, D-fructose, L-rhamnose, inositol, D-mannitol, D-maltose, D-sucrose, D-trehalose, D-raffinose, D-turanose and D-arabitol. It should be noted that all these C sources were also metabolized by the strains of Ensifer saheli, E. terangae, E. meliloti and E. fredii tested by De Lajudie et al. (1994).

\section{Genome-based species delineation}

Two genome-based species delineation methods were used to show that the species Ensifer aridi is distinct to already defined species. When we compared the genomes of the six E. aridi strains to available sequences of Ensifer type strains, both ANI and dDDH were well under the thresholds of $95 \%$ and $70 \%$, respectively with $\%$ values ranging from
81.2 to 85.7 for ANI and 23.1-29.8 for dDDH (Fig. 6). The phylogenomic tree obtained with TYGS automated pipeline showed, as expected, that the genomes of Ensifer strains belonging to the same species of $E$. meliloti, E. medicae, $E$. fredii or E. americanum presented ANI and dDDH above thresholds and TYGS classified them as distinct species accordingly. Finally, TYGS clustered all six E. aridi strains (sharing 98.8-99.9\% ANI and 87.9-99.1 dDDH \%) together within a yet not defined species whose closest relative is $E$. saheli (Fig. 6).

\section{Discussion}

In this work, we characterized a collection of ten salt-tolerant rhizobial isolates originating from nodules of Phaseolus filiformis a wild bean native of northwestern Mexico growing on a sandy alkaline soil. These strains were also capable of developing the symbiosis with five cultivated bean varieties tested (Negro jamapa, peruano, pinto, vaquita and alubia). 
Fig. 5 Maximum-likelihood tree based on nifH partial gene sequences showing the evolutionary relationships between Ensifer strains isolated from Phaseolus filiformis nodules in Mexico (bold) and selected strains. The analysis was based on 652 nucleotides alignment. The significance of each branch is indicated by the bootstrap value calculated for 500 replicates (only values higher than $50 \%$ are indicated). Scale bar indicates 5\% substitution per site. Accession numbers of sequences used are reported in supplementary Table S2

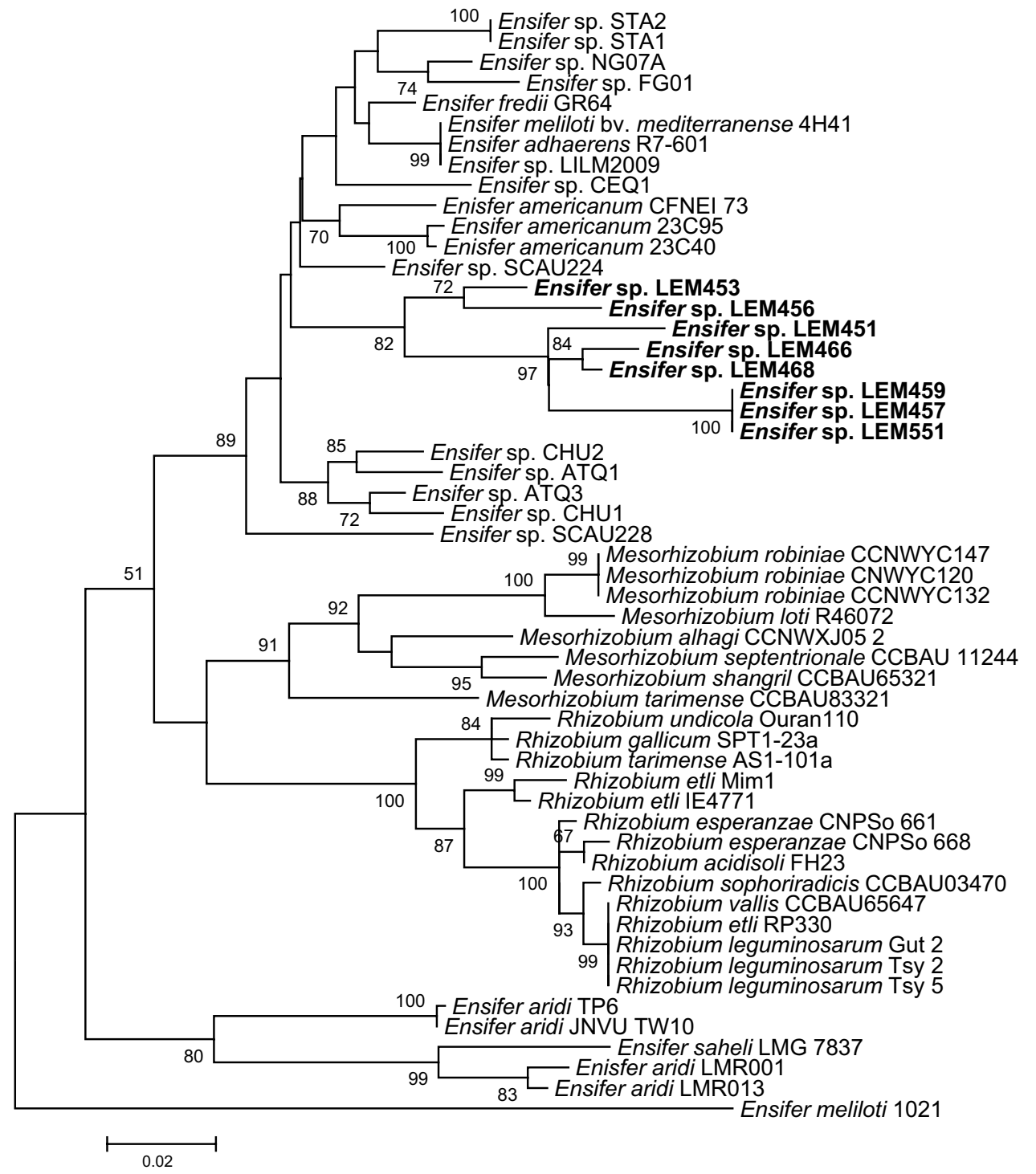

Classification of rhizobia has gone through substantial changes in recent years due to the addition of new genera and species to this important group of bacteria. Rhizobia isolated from most Phaseolus species (including P. filiformis) generally belong to the genus Bradyrhizobium (Servín-Garcidueñas et al. 2014), except for P. vulgaris, where Rhizobium is found to be the most abundant symbiotic bacteria (Martínez et al. 1985; Piñero et al. 1988; Somasegaran et al. 1991; Souza et al. 1994; Silva et al. 1999; Parker 2002; Ormeño-Orrillo et al. 2006). Nevertheless, Phaseolus vulgaris is recognized as a non-selective host for nodulation (Michiels et al. 1998) and Ensifer strains or species (E. fredii, E. medicae, E. meliloti and E. americanum) have also been reported as Phaseolus symbionts in several continents (Bernal and Graham 2001; Mhamdi et al. 2002; Parker 2002; Wang et al. 2009; Mnasri et al. 2012; Adhikari et al. 2013; Verástegui-Valdés et al. 2014).
By analyzing the $16 \mathrm{~S}$ rDNA sequences, we found that all the ten rhizobacteria isolated from Phaseolus filiformis belong to the genus Ensifer. 16S rDNA-based phylogenies indicated that eight of the isolates recovered here were, however, clustered together with the recently proposed species "Ensifer aridi" or E. kostiense which diverge from species already shown to develop an effective symbiosis with bean.

Taxonomical identifications based on 16S rDNA analysis is sometimes not powerful enough to discriminate the phylogenetic position of closely related strains or species due to high levels of sequence conservation (Acinas et al. 2004; Martens et al. 2007). The use of several loci present in single copies on genomes with greater sequence divergence and evenly distributed in the genome is an alternative approach that overcomes the drawbacks of 16S rDNA-based analyses (Vandamme et al. 1996; Stackebrandt et al. 2002; Zeigler 2003; Gevers et al. 2005; Thompson et al. 2005). To clarify 
Table 2 Effect of temperature, salt concentration and $\mathrm{pH}$ of medium on bacterial growth of Ensifer strains isolated from P. filiformis in Mexico

\begin{tabular}{|c|c|c|c|c|c|c|c|c|c|c|c|c|c|c|c|c|c|c|c|c|}
\hline \multirow[t]{2}{*}{ Strains } & \multicolumn{4}{|c|}{$\begin{array}{l}\text { Bacterial growth in } \\
\text { YMA at different } \\
\text { temperature condi- } \\
\text { tions }\left({ }^{\circ} \mathrm{C}\right)\end{array}$} & \multicolumn{12}{|c|}{ Bacterial growth in YMA with $\mathrm{NaCl}$ at different concentrations (mM) } & \multicolumn{4}{|c|}{$\begin{array}{l}\text { Growth in YMA } \\
\text { medium at different } \\
\text { pH conditions }\end{array}$} \\
\hline & 28 & 32 & 37 & 40 & 0.085 & 10 & 50 & 100 & 150 & 200 & 300 & 400 & 500 & 600 & 800 & 1000 & 5.3 & 6.8 & 8.3 & 9.5 \\
\hline \multicolumn{21}{|l|}{ Mexican strains } \\
\hline LEM451 & ++ & ++ & ++ & ++ & ++ & ++ & ++ & ++ & ++ & ++ & ++ & + & + & + & + & W & $\mathrm{W}$ & ++ & ++ & ++ \\
\hline LEM453 & ++ & ++ & ++ & ++ & ++ & ++ & ++ & ++ & ++ & ++ & + & - & - & - & - & - & W & ++ & ++ & ++ \\
\hline LEM551 & ++ & ++ & ++ & ++ & ++ & ++ & ++ & ++ & ++ & ++ & + & - & - & - & - & - & + & ++ & ++ & + \\
\hline LEM456 & ++ & ++ & ++ & ++ & + & ++ & ++ & ++ & ++ & + & + & W & W & - & - & - & + & + & ++ & ++ \\
\hline LEM457 & + & ++ & ++ & + & + & + & + & + & + & + & + & W & - & - & - & - & - & ++ & ++ & ++ \\
\hline LEM459 & + & + & + & ++ & ++ & ++ & + & + & + & + & + & W & - & - & - & - & - & ++ & ++ & ++ \\
\hline LEM462 & ++ & ++ & ++ & ++ & ++ & ++ & ++ & ++ & ++ & + & + & - & - & - & - & - & + & ++ & ++ & ++ \\
\hline LEM465 & + & + & + & + & + & ++ & + & + & + & + & + & W & W & - & - & - & - & + & + & + \\
\hline LEM466 & + & + & + & + & + & + & + & + & + & + & + & + & + & + & - & - & - & + & + & + \\
\hline LEM468 & ++ & ++ & ++ & + & + & + & + & + & + & + & + & - & - & - & - & & W & + & ++ & ++ \\
\hline E. saheli LMG8310 & + & ++ & ++ & ++ & ++ & ++ & ++ & ++ & ++ & ++ & ++ & + & $\mathrm{W}$ & W & - & - & + & ++ & ++ & ++ \\
\hline
\end{tabular}

++ Vigorous growth

+ Good growth

W Weak growth

- No growth

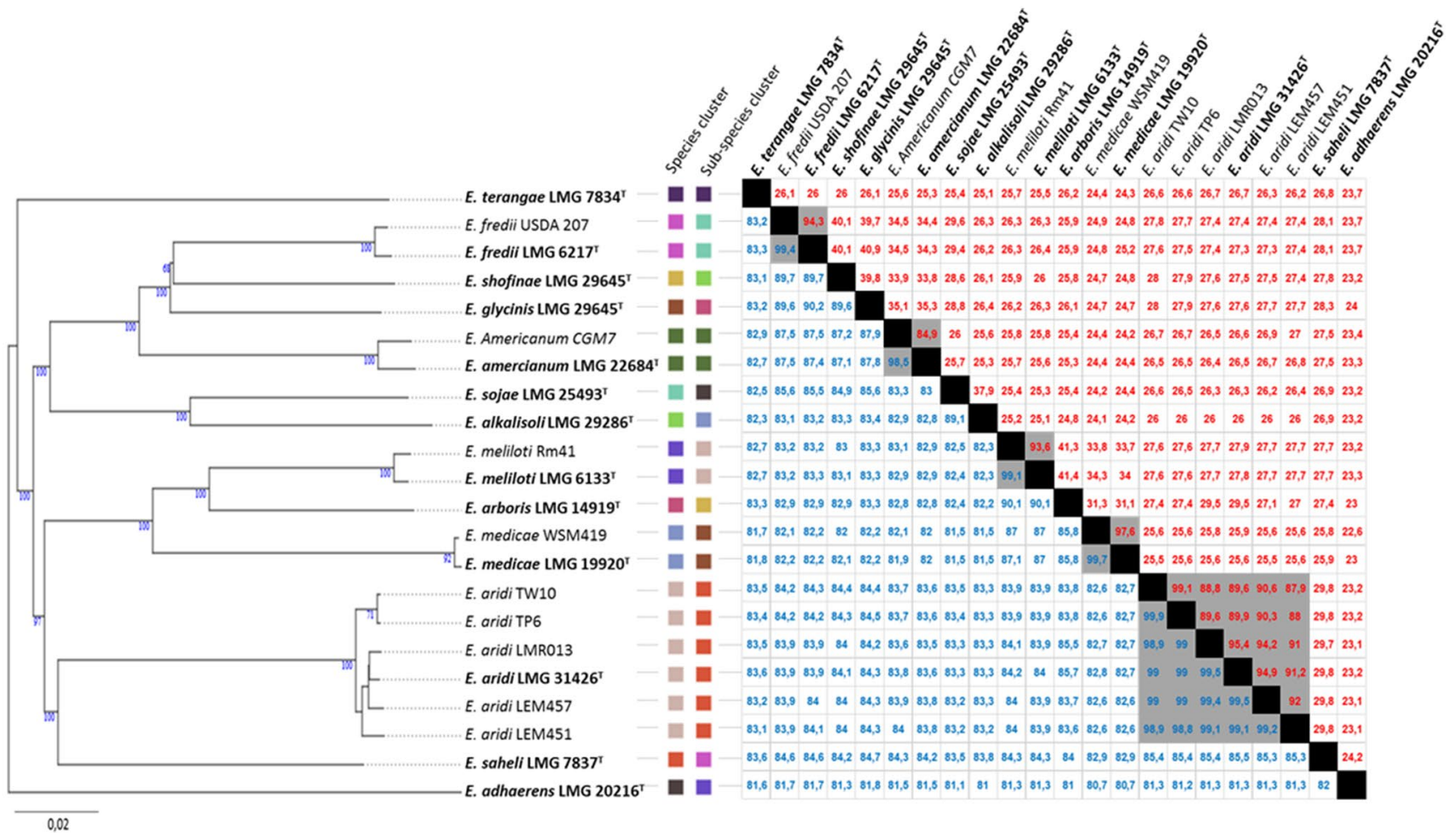

Fig. 6 Genome-based species delineation. Phylogenomic tree inferred from GBDP distances obtained with TYGS. Branch lengths are scaled in terms of GBDP distance formula d5; numbers above branches are GBDP pseudo-bootstrap support values from 100 replications. Leaf labels are colored by affiliation to species and subspe- cies clusters. The matrix on the right shows ANI (lower left, blue font) and dDDH (upper right, red font) obtained upon pairwise comparisons. Values above thresholds for intraspecies comparisons are highlighted in gray. Type strains are indicated by bold font. Accession numbers of sequences used are reported in supplementary Table S3 
the taxonomic position of Phaseolus filiformis isolates presented here, eight gene fragments ( $a t p D, d n a K, r p o B, g \ln A$, gyr $B, \operatorname{thr} C, \operatorname{rec} A$ and $g \ln I I$ ) were sequenced and analyzed. The phylogenetic relationships obtained using atpD, recA and $g I n I I$, genes that have been sequenced in most Ensifer species showed that there might be several species among the isolated strains. One strain (LEM456) was grouped with E. meliloti, while the remaining strains isolated from $P$. filiformis were sharing a separate clade with strains of "Ensifer aridi" that, based on comparative genomics, includes the strains LEM451 and LEM457 (Le Queré et al. 2017). The use of six housekeeping genes ( $a t p D, r p o B, g y r B, t h r C, r e c A$ and $g \ln I I$ ) for MLSA confirmed that the strain LEM456 is related to Ensifer meliloti, while the other strains clustered with "Ensifer aridi"; being different from already described Ensifer species nodulating Phaseolus, including E. americanum, a dominant $P$. vulgaris symbiont isolated from alkaline soils in Mexico (Verástegui-Valdés et al. 2014). Our results enlarge the spectrum of rhizobial species that can nodulate Phaseolus species and further support a shift toward Ensifer strains as preferred bean symbiont in alkaline soils.

Phylogenies obtained with symbiotic genes were not congruent with those obtained using housekeeping genes. According to the nodC phylogeny, all strains reported here clustered together including LEM456 which was, based on MLSA, clustering with E. meliloti strains. Surprisingly, the greatest nodC sequence similarities were found with Ensifer strains isolated from Acacia macracantha nodules in Peru which possess 16S rDNA sequences highly similar to the species Ensifer fredii, E. americanum, or E. meliloti (Cordero et al. 2016). However, the clade regrouping nodC sequences from $P$. filiformis and these A. macracantha isolates also showed some proximity with another cluster encompassing nod $C$ sequences from $P$. vulgaris rhizobia belonging to the biovar mediterranense which included $E$. americanum, E. fredii and E. meliloti recovered from Tunisia, Spain or Mexico (Laguerre et al. 2001; Mnasri et al. 2007, 2012; Verástegui-Valdés et al. 2014). The nifH-based phylogenetic relationships of Mexican P. filiformis rhizobia indicated greater diversity, but they remained clustered together with sequences of Ensifer strains already shown to nodulate Phaseolus such as E. americanum. Interestingly the latter species was first described as Acacia symbionts in Mexico (Toledo et al. 2003), prior to being described as bean-nodulated rhizobia in Tunisian (Mnasri et al. 2007, 2012) and Mexican soils (Verástegui-Valdés et al. 2014) which demonstrates its broad geographical distribution and its capacity to exchange symbiotic gene arsenal to develop the symbiosis with multiple hosts. Based on the high similarity between $P$. filiformis rhizobia symbiotic genes sequences including that from the LEM456, our data support a local acquisition of this symbiotic gene pool through plasmid or genomic island transfers among Mexican bean-nodulating
Ensifer strains and species which may even occur at the intergeneric level (Andrews et al. 2018; Verástegui-Valdés et al. 2014).

Within their natural habitat, rhizobial species are frequently subjected to detrimental effects such as water or salt-induced osmotic stresses or high temperatures which affect bacterial growth and root colonization. In the case of E. americanum, isolates tolerate $170 \mathrm{mM} \mathrm{NaCl}$, but their growth is reduced at $260-340 \mathrm{mM}$ and completely inhibited at $400 \mathrm{mM} \mathrm{NaCl}$ (Verástegui-Valdés et al. 2014). Higher salt tolerance levels were shown for E. meliloti bv. mediterranense strains which could grow in media containing salt concentrations greater than $750 \mathrm{mM}$ (Mnasri et al. 2007). $E$. meliloti and $E$. medicae isolated from marginal soils affected by salt and drought, in arid regions of Morocco, have shown a large degree of variation for salt tolerance (Elboutahiri et al. 2010). E. medicae has shown good tolerance to $\mathrm{NaCl}$ (>513 mM), compared to other rhizobia species (Zahran 1999). E. meliloti shows greater tolerance to salt (1711 mM $\mathrm{NaCl}$ ) (Elboutahiri et al. 2010), indicating that saline soils naturally select strains more tolerant to salinity, and results in higher recovery of salinity-tolerant strains. All Mexican strains identified here were capable to grow at salt concentrations greater than $1.5 \%$ (about $250 \mathrm{mM}$ ), that was expected as they were recovered from beach saline sandy soil. Growth at salt concentrations greater than $400 \mathrm{mM}$ was observed in few strains, and one of them, LEM451, was even capable of growing at $1000 \mathrm{mM} \mathrm{NaCl}$; meanwhile, the most closely related Ensifer species E. saheli showed some growth up to $600 \mathrm{mM}$. Even though the tolerance to salt is highly variable both at the intra- or inter-specific levels, our results further demonstrate the relatively high salt tolerance of strains belonging to the genus Ensifer.

Ensifer americanum, E. meliloti bv. mediterranense and $E$. saheli strains have been shown to grow at $\mathrm{pH}$ ranging from 5.0 to 9.0, but not below 5.0 (Biswas et al. 2008; Verástegui-Valdés et al. 2014; this work). Despite some variations between strains studied in this report, the phenotypic characterization confirmed the particular adaptation of Ensifer toward alkaline $\mathrm{pH}$; furthermore, as shown for other Ensifer species and strains, they appeared less adapted to acid $\mathrm{pH}$. These data suggest that soil $\mathrm{pH}$ should be evaluated prior to application of rhizobial inocula to use the best adapted nitrogen-fixing bacteria in biofertilization programs.

The optimal growth of strains belonging to the genus Ensifer is generally obtained at temperatures around 25-33 ${ }^{\circ} \mathrm{C}$ (De Lajudie et al. 1994), but some species are capable of growing at temperatures ranges from $12{ }^{\circ} \mathrm{C}(\mathrm{Li}$ et al. 2011) to $44{ }^{\circ} \mathrm{C}$ (De Lajudie et al. 1994). All P. filiformis strains presented here were tolerant to high temperatures $\left(40^{\circ} \mathrm{C}\right)$, similarly to E. saheli (De Lajudie et al. 1994) or to strains belonging to the proposed species $E$. aridi (Le Queré et al. 2017), to which most of the presented isolates 
were belonging. This capacity to withstand high temperatures was expected when considering the biome from which they were isolated.

Phaseolus filiformis strains were phenotypically characterized for their carbon source utilization. Ensifer strain LEM551 had a particular biochemical behavior. This strain was not capable of utilizing most carbon sources tested, being slightly divergent from the clade that grouped nine wild bean rhizobia by MLSA. That strain may represent a distinct species related to $E$. aridi. However, the most evolutionary distant strain LEM456 (related to E. meliloti) presented a similar profile to that of strains forming this dominant group which shows, based on the $\mathrm{C}$ sources tested, a lack of correlation between metabolic activity and taxonomy, and further support metabolic versatility among rhizobia as shown previously even at the intraspecies level in Ensifer (Biondi et al. 2009; De Lajudie et al. 1994).

\section{Conclusion}

This study demonstrated that $P$. filiformis, a wild bean species native to the southwestern United States and northwestern Mexico is nodulated by rhizobial species belonging to the genus Ensifer. Among these wild bean rhizobia, one was related to E. meliloti and the others were clustering with "Ensifer aridi" a proposed new taxon yet only recovered from arid regions in America, Asia and Africa. Symbiotic gene-based phylogenies were incongruent with those obtained using housekeeping gene sequences suggesting a local exchange of this symbiotic gene through lateral gene transfers that mimics evolutionary histories of other Ensifer americanum and E. meliloti strains previously shown to nodulate $P$. vulgaris. Despite the high salinity conditions found in the beach sand where these symbiotic bacteria were isolated, salt tolerance was variable between isolates which nevertheless could all grow in presence of nearly $300 \mathrm{mM}$ $\mathrm{NaCl}$. These strains tolerate high $\mathrm{pH}$ rather than acidic conditions. They are also capable of growing at temperatures from $28{ }^{\circ} \mathrm{C}$ to at least $40{ }^{\circ} \mathrm{C}$ and were in majority capable of utilizing a wide range of carbohydrates and organic acids as sole carbon sources for growth. Capable of developing symbiosis with several Phaseolus species and cultivated bean varieties, these new strains present potential interest in biotechnology and should be further tested for their biofertilizing potential especially in alkaline soils subjected to salinization and heat, thanks to their phenotypic characteristics.

\section{Description of Ensifer aridi sp. nov.}

Ensifer aridi (aridi, a diminutive of N.L. Fem ariditas is referring to the areas where all the strains from this new species where isolated from and which are subjected to droughts: these are the deserts of Thar in India, Merzouga in Morocco and here Baja California). Cells are Gramnegative, aerobic, motile and do not produce spores. Colonies are circular, from slightly to highly mucous, white opaque, convex and 1-3 mm diameter upon $48 \mathrm{~h}$ of growth on YMA medium at $30{ }^{\circ} \mathrm{C}$. They can grow at particularly high temperatures $\left(40{ }^{\circ} \mathrm{C}\right)$, tolerate $\mathrm{pH}$ ranging from 6 to 9.5 and all Ensifer aridi strains tested including the eight Mexican, the two Moroccan (LMR001, LMR013) and the two Indian (TP6, TW10) isolates were capable of growing using glycerol, L-arabinose, D-fructose, L-rhamnose, inositol, D-mannitol, D-maltose, D-sucrose, D-trehalose, D-raffinose, D-turanose or D-arabitol as sole carbon sources (Sakrouhi et al. 2016; Le Queré et al. 2017). The type strain is Ensifer aridi $\mathrm{LMR} 001^{\mathrm{T}}\left(=\mathrm{LMG} 31426^{\mathrm{T}} ;=\right.$ HAMBI $\left.3707^{\mathrm{T}}\right)$ isolated from Moroccan Merzouga desert sand dune (GPS coordinates: N 31 $\left.{ }^{\circ}{ }^{\prime} 42.7^{\prime \prime} / \mathrm{W} 3^{\circ} 57^{\prime} 56.1^{\prime \prime}\right)$ using Vachellia gummifera as a host (Sakrouhi et al. 2016). The genome sequence of the type strain is accessible under the Genbank accession LUAV00000000.1 together with those of five other strains including the Mexican strains LEM451 and LEM457 (Accessions LUFV00000000.1 and LUFW00000000.1, respectively) (Le Queré et al. 2017). Strains belonging to this new species present variable accessory genomes that explain the variable host ranges and $\mathrm{C}$ sources they can utilize (Le Queré et al. 2017). The DNA G + C content of strain LMR $001^{\mathrm{T}}$ was $61.7 \mathrm{~mol} \%$. Using the genome sequence of E. aridi $\mathrm{LMR} 001^{\mathrm{T}}$ as query, the highest ANI and $\mathrm{dDDH}$ values were found for the closest relative $E$. saheli $\mathrm{LMG}$ $7837^{\mathrm{T}}$ with, respectively, $85.4 \%$ and $29.8 \%$ which clearly demonstrates that Ensifer aridi strains (NCBI:txid1708715) sharing more than $99 \%$ ANI and $87.9 \%$ dDDH belong to a new species within the genus Enisfer.

Acknowledgements This work was supported by the project SEPCONACYT-ANUIES-ECOS NORD France M08-A02. Rocha G (242743), Cuéllar A (220626) and Medina A (273344) are grateful for grants from CONACyT. The authors wish to thank Vicerrectoría de Investigación y Estudios de Posgrado (VIEP-BUAP 00075) and Institut de Recherche pour le Développement (IRD) for supplying additional financial assistance. The authors wish to thank Esperanza Martínez for kindly providing E. saheli strain LMG8310 (ORS611), and Dolores Castañeda for physicochemical analyses of soils.

\section{Compliance with ethical standards}

Conflict of interest The authors declare that they have no conflict of interest.

Open Access This article is distributed under the terms of the Creative Commons Attribution 4.0 International License (http://creativeco mmons.org/licenses/by/4.0/), which permits unrestricted use, distribution, and reproduction in any medium, provided you give appropriate credit to the original author(s) and the source, provide a link to the Creative Commons license, and indicate if changes were made. 


\section{References}

Acinas SG, Klepac-Ceraj V, Hunt DE, Pharino C, Ceraj I, Distel DL, Polz MF (2004) Fine-scale phylogenetic architecture of a complex bacterial community. Nature 430:551-554

Adhikari D, Itoh K, Suyama K (2013) Genetic diversity of common bean (Phaseolus vulgaris L.) nodulating rhizobia in Nepal. Plant Soil 368:341-353

Andrews M, De Meyer S, James EK, Stępkowski T, Hodge S, Simon MF, Young JPW (2018) Horizontal transfer of symbiosis genes within and between rhizobial genera: occurrence and importance. Genes 9(7):321. https://doi.org/10.3390/genes9070321

Bergersen FJ (1961) The growth of rhizobium in synthetic media. Aust J Biol Sci 14:349-360

Bernal G, Graham PH (2001) Diversity in the rhizobia associated with Phaseolus vulgaris L. in Ecuador, and comparisons with Mexican bean rhizobia. Can J Microbiol 47:526-534

Beynon JL, Beringer JF, Johnonston AWB (1980) Plasmids and hostrange in Rhizobium leguminosarum and Rhizobium phaseoli. J Gen Microbiol 120:421-429

Biondi EG, Tatti E, Comparini D, Giuntini E, Mocali S, Giovannetti L, Bazzicalupo M, Mengoni A, Viti C (2009) Metabolic capacity of Sinorhizobium (Ensifer) meliloti strains as determined by phenotype microarray analysis. Appl Environ Microbiol 75:5396-5404

Biswas S, Das RH, Sharma GL, Das HR (2008) Isolation and characterization of a novel cross-infective rhizobia from Sesbania esculenta (Dhaincha). Curr Microbiol 56:48-54

Chen WM, Moulin L, Bontemps C, Vandamme P, Bena G, BoivinMasson C (2003) Legume symbiotic nitrogen fixation by betaproteobacteria is widespread in nature. $\mathrm{J}$ Bacteriol 24:7266-7272

Cordero I, Ruiz-Díez B, Coba de la Peña T, Balaguer L, Lucas MM, Rincón A, Pueyo JJ (2016) Rhizobial diversity, symbiotic effectiveness and structure of nodules of Vachellia macracantha. Soil Biol Biochem 96:39-54

Corral-Lugo A, Morales-García YE, Pazos-Rojas LA, Ramírez-Valverde A, Martínez-Conteras RD, Muñoz-Rojas J (2012) Quantification of cultivable bacteria by "Massive stamping drop plate" method. Rev Colomb Biotecnol 14:147-156

Dall'Agnol RF, Plotegher F, Souza RC, Mendes IC, Dos Reis Junior FB, Bena G, Moulin L, Hungria M (2016) Paraburkholderia nodosa is the main N2-fixing species trapped by promiscuous common bean (Phaseolus vulgaris L.) in the Brazilian 'Cerradão'. FEMS Microbiol Ecol 92(8):108. https://doi.org/10.1093/femsec/fiw108

De Lajudie P, Willems A, Pot B, Dewettinck D, Maestrojuan G, Neyra M, Collins MD, Dreyfus B, Kersters K, Gillis M (1994) Polyphasic taxonomy of rhizobia. Emendation of the genus Sinorhizobium and description of Sinorhizobium meliloti comb. nov., Sinorhizobium saheli sp. nov. and Sinorhizobium teranga sp. nov. Int J Syst Bactieriol 44:715-733

Elboutahiri N, Thami-Alami I, Udupa SM (2010) Phenotypic and genetic diversity in Sinorhizobium meliloti and S. medicae from drought and salt affected regions of Morocco. BMC Microbiol 10(15)

Gaunt MW, Turner SL, Rigottier-Gois L, Lloyd-Macgilp SA, Young JP (2001) Phylogenies of atpD and recA support the small subunit rRNA-based classification of rhizobia. Int J Syst Evol Microbiol 51:2037-2048

Gevers D, Cohan FM, Lawrence JG, Spratt BG, Coenye T, Feil EJ, Stackebrandt E, De Peer YV, Vandamme P, Thompson FL, Swings J (2005) Re-evaluating prokaryotic species. Nat Rev Microbiol 3:733-739

Goris J, Konstantinidis KT, Klappenbach JA, Coenye T, Vandamme P, Tiedje JM (2007) DNA-DNA hybridization values and their relationship to whole-genome sequence similarities. Int J Syst Evol Microbiol 57:81-91
Haukka K, Lindstrom K, Young JP (1998) Three phylogenetic groups of $\operatorname{nodA}$ and nifH genes in Sinorhizobium and Mesorhizobium isolates from leguminous trees growing in Africa and Latin America. Appl Environ Microbiol 64:419-426

Herrera-Cervera JA, Caballero-Mellado J, Laguerre G, Tichy HV, Requena N, Amarger N, Martinez-Romero E, Olivares J, Sanjuan J (1999) At least five rhizobial species nodulate Phaseolus vulgaris in a Spanish soil. FEMS Microbiol Ecol 30:87-97

Hickman JC (ed) (1993) The Jepson manual: higher plants of California. University of California Press, Berkeley

Knight CD, Rossen L, Robertson JG, Wells B, Downie JA (1986) Nodulation inhibition by Rhizobium leguminosarum multicopy nod $\mathrm{ABC}$ genes and analysis of early stages of plant infection. $\mathrm{J}$ Bacteriol 166:552-558

Kumar S, Stecher G, Tamura K (2016) MEGA7: molecular evolutionary genetics analysis version 7.0 for bigger datasets. Mol Biol Evol 33:1870-1874

Laguerre G, Nour SM, Macheret V, Sanjuan J, Drouin P, Amarger N (2001) Classification of rhizobia based on nodC and nifH gene analysis reveals a close phylogenetic relationship among Phaseolus vulgaris symbionts. Microbiology 147:981-993

Le Queré A, Tak N, Gehlot HS, Lavire C, Meyer T, Chapulliot D, Rathi S, Sakrouhi I, Rocha G, Rohmer M, Severac D, FilaliMaltouf A, Munive JA (2017) Genomic characterization of Ensifer aridi, a proposed new species of nitrogen-fixing rhizobium recovered from Asian, African and American deserts. BMC Genom 18:85. https://doi.org/10.1186/s12864-016-3447-y

Lewis G, Schrire B, Mackinder B, Lock M (eds) (2005) Legumes of the world. In: Kew scientist. Kew Publishing, London

Li QQ, Wang ET, Chang YL, Zhang YZ, Zhang YM, Sui XH, Chen WF, Chen WX (2011) Ensifer sojae sp. nov., isolated from root nodules of Glycine max grown in saline-alkaline soils. Int J Syst Evol Microbiol 61:1981-1988

Librado P, Rozas J (2009) DnaSP v5: a software for comprehensive analysis of DNA polymorphism data. Bioinformatics 25:1451-1452

Lindström K (2015) Evolution and taxonomy of nitrogen-fixing organisms with emphasis on rhizobia. In: De Bruijn FJ (ed) Biological nitrogen fixation. Wiley, Hoboken

Lindström K, Mousavi SA (2010) Rhizobium and other N-fixing symbiosis. In: Encyclopedia of life sciences (ELS). Wiley, Chichester. https://doi.org/10.1002/9780470015902.a0021157

Mabberly DJ (1997) The plant book. Cambridge University Press, Cambridge

Martens M, Delaere M, Coopman R, De Vos P, Gillis M, Willems A (2007) Multilocus sequence analysis of Ensifer and related taxa. Int J Syst Evol Microbiol 57:489-503

Martens M, Dawyndt P, Coopman R, Gillis M, de Vos P, Willems A (2008) Advantages of multilocus sequence analysis for taxonomic studies: a case study using 10 housekeeping genes in the genus Ensifer (including former Sinorhizobium). Int J Syst Evol Microbiol 58:200-214

Martínez E, Pardo MA, Palacios R, Cevallos MA (1985) Reiteration of nitrogen fixation gene sequences and specificity of Rhizobium in nodulation and nitrogen fixation in Phaseolus vulgaris. J Gen Microbiol 131:1779-1786

Martinez-Romero E (2009) Coevolution in Rhizobium-legume symbiosis? DNA Cell Biol 28:361-370

Meier-Kolthoff JP, Göker M (2019) TYGS is an automated highthroughput platform for state-of-the-art genome-based taxonomy. Nat Commun 10:2182. https://doi.org/10.1038/s41467-019-10210 $-3$

Meier-Kolthoff JP, Auch AF, Klenk HP, Göker M (2013) Genome sequence-based species delimitation with confidence intervals and improved distance functions. BMC Bioinform 14:60. https:// doi.org/10.1186/1471-2105-14-60 
Mhamdi R, Laguerre G, Aouani ME, Mars M, Amarger N (2002) Different species and symbiotic genotypes of field rhizobia can nodulate Phaseolus vulgaris in Tunisian soils. FEMS Microbiol Ecol 41:77-84

Michiels J, Dombrecht B, Vermeiren N, Xi C, Luyten E, Vanderleyden $\mathrm{J}$ (1998) Phaseolus vulgaris is a non-selective host for nodulation. FEMS Microbiol Ecol 26:193-205

Mnasri B, Mrabet M, Laguerre G, Aouani ME, Mhamdi R (2007) Salttolerant rhizobia isolated from a Tunisian oasis that are highly effective for symbiotic N2-fixation with Phaseolus vulgaris constitute a novel biovar (bv. mediterranense) of Sinorhizobium meliloti. Arch Microbiol 187:79-85

Mnasri B, Saidi S, Chihaoui SA, Mhamdi R (2012) Ensifer americanum sym-biovar mediterranense is a predominant symbiont that nodulates and fixes nitrogen with common bean (Phaseolus vulgaris L.) in a Northern Tunisian field. Syst Appl Microbiol 35:263-269

Moulin L, Munive A, Dreyfus B, Boivin-Masson C (2001) Nodulation of legumes by members of the $\beta$-subclass of proteobacteria. Nature 411:948-950

Nicholas KB, Nicholas HBJ, Deerfield DWI (1997) GeneDoc: analysis and visualization of genetic variation. Embnew News 4:1-14

Olive DM, Bean P (1991) Principles and applications of methods for DNA-based typing of microbial organisms. J Clin Microbiol 37:1661-1669

Ormeño-Orrillo E, Vinuesa P, Zúñiga-Dávila D, Martínez-Romero E (2006) Molecular diversity of native bradyrhizobia isolated from Lima bean (Phaseolus lunatus L.) in Peru. Syst Appl Microbiol 29:253-262

Parker MA (2002) Bradyrhizobia from wild Phaseolus, Desmodium, and Macroptilium species in Northern Mexico. Appl Environ Microbiol 68:2044-2048

Piñero D, Martinez E, Selander RK (1988) Genetic diversity and relationships among isolates of Rhizobium leguminosarum biovar phaseoli. Appl Environ Microbiol 54:2825-2832

Ribeiro RA, Barcellos FG, Thompson FL, Hungria M (2009) Multilocus sequence analysis of Brazilian Rhizobium microsymbionts of common bean (Phaseolus vulgaris L.) reveals unexpected taxonomic diversity. Res Microbiol 160:297-306

Roskov YR, Bisby FA, Zarucchi JL, White RJ (2013) ILDIS World Database of Legumes (version 10.04, Sep 2012). In: Roskov Y, Kunze T, Paglinawan L, Orrell T, Nicolson D, Culham A, Bailly N, Kirk P, Bourgoin T, Baillargeon G, Hernandez F, De Wever A (eds) Species 2000 and ITIS Catalogue of Life, 2013 Annual Checklist. Species 2000, Reading

Sakrouhi I, Belfquih M, Sbabou L, Moulin P, Bena G, Filali-Maltouf A, Le Quéré A (2016) Recovery of symbiotic nitrogen fixing acacia rhizobia from Merzouga Desert sand dunes in South East Morocco-Identification of a probable new species of Ensifer adapted to stressed environments. Syst Appl Microbiol 39:122-131

Servín-Garcidueñas LE, Zayas-Del Moral A, Ormeño-Orrillo E, Rogel MA, Delgado-Salinas A, Sánchez F, Martínez-Romero E (2014) Symbiont shift towards Rhizobium nodulation in a group of phylogenetically related Phaseolus species. Mol Phylogenet Evol 79:1-11

Shreve F, Wiggins IL (1964) Vegetation and flora of the Sonoran desert. Stanford University Press, Stanford

Silva C, Eguiarte L, Souza V (1999) Reticulated and epidemic genetic structure of Rhizobium etli biovar phaseoli in traditionally managed locality in Mexico. Mol Ecol 8:277-287

Somasegaran P, Hoben HJ (1994) Handbook for rhizobia. Methods in legume-rhizobium technology. Springer, New York

Somasegaran P, Hoben HJ, Lewison L (1991) Symbiotic interactions of Phaseolus acutifolius and $P$. acutifolius X $P$. vulgaris hybrid progeny in symbiosis with Bradyrhizobium spp. and Rhizobium leguminosarum bv. phaseoli. Can J Microbiol 37:497-503

Souza V, Eguiarte L, Avila G, Capello R, Gallardo C, Montoya J, Piñero D (1994) Genetic structure of Rhizobium etli biovar phaseoli associated with wild and cultivated bean plants (Phaseolus vulgaris and $P$. coccineus) in Morelos, Mexico. Appl Environ Microbiol 60:1260-1268

Stackebrandt E, Frederiksen W, Garrity GM, Grimont PAD, Kampfer P, Maiden MC, Nesme X, Rossello-Mora R, Swings J, Truper HG, Vauterin L, Ward AC, Whitman WB (2002) Report of the ad hoc committee for the reevaluation of the species definition in bacteriology. Int J Syst Evol Microbiol 52:1043-1047

Stepkowski T, Czaplinska M, Miedzinska K, Moulin L (2003) The variable part of the dnaK gene as an alternative marker for phylogenetic studies of rhizobia and related alpha Proteobacteria. Syst Appl Microbiol 26:483-494

Tamura K, Peterson D, Peterson N, Stecher G, Nei M, Kumar S (2011) MEGA5: molecular evolutionary genetics analysis using maximum likelihood, evolutionary distance, and maximum parsimony methods. Mol Biol Evol 28:2731-2739

Thompson JD, Gibson TJ, Plewniak F, Jeanmougin F, Higgins DG (1997) The CLUSTAL-X windows interface: flexible strategies for multiple sequence alignment aided by quality analysis tools. Nucleic Acids Res 25:4876-4882

Thompson FL, Gevers D, Thompson CC, Dawyndt P, Naser S, Hoste B, Munn CB, Swings J (2005) Phylogeny and molecular identification of vibrios on the basis of multilocus sequence analysis. Appl Environ Microbiol 71:5107-5115

Toledo I, Lloret L, Martínez-Romero E (2003) Sinorhizobium americanus sp. nov., a new Sinorhizobium species nodulating native Acacia spp. in Mexico. Syst Appl Microbiol 26:54-64

Vandamme P, Pot B, Gillis M, De Vos P, Kersters K, Swings J (1996) Polyphasic taxonomy, a consensus approach to bacterial systematics. Microbiol Rev 60:407-438

Verástegui-Valdés MM, Zhang YJ, Rivera-Orduña FN, Cheng HP, Sui XH, Wang ET (2014) Microsymbionts of Phaseolus vulgaris in acid and alkaline soils of Mexico. Syst Appl Microbiol 37:605-612

Versalovic J, Schneider M, De Bruijn FJ, Lupski JR (1994) Genomic fingerprinting of bacteria using repetitive sequence-based polymerase chain reaction. Methods Mol Cell Biol 5:25-40

Vincent JM (1970) A manual for the practical study of the root-nodule bacteria. IBP Handbook No. 15. Blackwell Scientific Publication. Ltd., Oxford

Vinuesa P, Silva C, Werner D, Martínez-Romero E (2005) Population genetics and phylogenetic inference in bacterial molecular systematics: the roles of migration and recombination in Bradyrhizobium species cohesion and delineation. Mol Phylogenet Evol 34:29-54

Vinuesa P, Rojas-Jiménez K, Contreras-Moreira B, Mahna SK, Prasad BN, Moe H, Selvaraju SB, Thierfelder H, Werner D (2008) Biogeography and evolutionary genetics of four Bradyrhizobium species that nodulate soybeans on the Asiatic continent, assessed by multilocus sequence analysis. Appl Environ Microbiol 74:6987-6996

Wang H, Man CX, Wang ET, Chen WX (2009) Diversity of rhizobia and interactions among the host legumes and rhizobial genotypes in an agricultural-forestry ecosystem. Plant Soil 314:169-182

Zahran HH (1999) Rhizobium-legume symbiosis and nitrogen fixation under severe conditions and in arid climate. Microbiol Mol Biol Rev 63(4):968-989

Zeigler DR (2003) Gene sequences useful for predicting relatedness of whole genomes in bacteria. Int J Syst Evol Microbiol 53:1893-1900

Zurdo-Piñeiro JL, García-Fraile P, Rivas R, Peix A, León-Barrios M, Willems A, Mateos PF, Martínez-Molina E, Velázquez E, van Berkum P (2009) Rhizobia from Lanzarote, the Canary Islands, that nodulate Phaseolus vulgaris have characteristics in common with Sinorhizobium meliloti isolates from mainland Spain. Appl Environ Microbiol 75:2354-2359

Publisher's Note Springer Nature remains neutral with regard to jurisdictional claims in published maps and institutional affiliations. 